\title{
Institutions for Stable Prices: How To Design an Optimal Central Bank Law
}

\author{
William Poole
}

am pleased to be here today to discuss an extremely important topic. But I believe it wise to begin on a humble note. The title of this session includes the phrase "optimal central bank law." In designing a central bank law, we do not have a well-specified mathematical model to optimize, and consequently we cannot expect to find the optimal law. It would be a mistake, I believe, to be so bold as to recommend a legal framework for all countries for all time. The fact is that most high-income countries today, and many low- and middle-income countries, have achieved a high degree of success in maintaining low inflation, even though laws in these countries display substantial differences. We need to think rather abstractly about the design of the legal framework for the central bank and recognize that there are different ways to achieve the same end.

We should also recognize that success in achieving low and stable inflation, or price stability if you prefer that formulation, is relatively recent. We may well discover that some institutional arrangements are more robust over time, as we observe how various arrangements stand up to stresses not yet observed.

An institution as important as a central bank cannot take a particular form without substantial public understanding of the reasons for that form. A century ago, most informed people believed that the only sound basis for a monetary system was for paper money to be convertible into gold. For some years after World War II, most observers believed that fixed exchange rates were essential to monetary stability. Clearly, popular opinion and understanding of economic ideas imposes limits on our ability to transform the economy by changing laws.

\footnotetext{
William Poole is the president of the Federal Reserve Bank of St. Louis. This article was adapted from a speech of the same title presented at the First Conference of the Monetary Stability Foundation at the Regional Office of the Deutsche Bundesbank, Frankfurt, Germany, December 5, 2002. The author thanks colleagues at the Federal Reserve Bank of St. Louis for their comments, especially William T. Gavin and Robert H. Rasche. The views expressed do not necessarily reflect official positions of the Federal Reserve System.

(C) 2003, The Federal Reserve Bank of St. Louis.
}

Before proceeding, I want to emphasize that the views I express here are mine and do not necessarily reflect official positions of the Federal Reserve System. I thank my colleagues at the Federal Reserve Bank of St. Louis for their comments, but I retain full responsibility for errors.

I'll organize my thoughts in four sections. In the first, very brief section, I'll discuss economic principles. I start there because the legal framework within which a central bank operates must be consistent with the way a market system works, and the goals assigned to a central bank must be within its power to achieve. Next, I'll discuss central bank law consistent with economic principles and, in a separate section because of its importance, the design of central bank independence. Finally, I'll address the issue of central bank transparency.

To make the exposition a bit easier, I'll refer to the leadership of a central bank as the "governor," which will refer to the governor, chairman, or governing board as appropriate. I'll refer to the top elected official of the government as the "president," which will refer to the president or prime minister as appropriate.

\section{ECONOMIC PRINCIPLES}

The logical place to begin an analysis of how to design an optimal central bank law is with a simple statement of economic principles. The principles I believe should guide our thinking are these:

- Inflation, anticipated and especially unanticipated, above some threshold rate is costly. Deflation is also costly. Costs are low when the departure of the rate of price change, whether above or below the threshold rate, is small; costs are larger when the departure is larger. The evidence suggests that the costs of departures are not symmetric; deflation of 5 percent per year is likely to be much more costly than inflation of 5 percent per year.

- There is no long-run tradeoff between inflation and unemployment, and the short-run tradeoff may well be too unreliable to be useful for policymakers. 
- Market expectations about future monetary policy (and future economic policies generally) are extremely important in determining how well monetary policy will work.

\section{CENTRAL BANK LAW}

Because inflation and deflation are costly, a central bank ought to have an inflation target. I believe that the appropriate target is zero inflation, properly measured - that is, abstracting from measurement errors in price indexes. Others believe that a small, positive rate of inflation is appropriate. The difference between 0 and, say, 2 percent inflation per year is a minor matter relative to other issues. In particular, reasonable stability in the rate of inflation and especially in the expected rate of inflation over the medium term are more important than whether the target rate is 0 or 2 percent per year. Whether the target is expressed as a point or a range is an interesting issue, but not fundamental.

I personally favor a legislated inflation target, but whether the target is legislated is not the main issue. If the weight of public opinion is not behind a legislated target, it will not be effective. The United States does not have a legislated target, but since the mid-1990s the Federal Reserve has been successful in achieving and maintaining a low average rate of inflation. What is needed is not so much a legislated inflation target but a target framework that the public regards as having constitutional force. In the United States, the gold standard used to have constitutional force even though it was never written into the Constitution explicitly.

What I mean by "constitutional force" is that a law or practice cannot be changed without resort to lengthy discussion and, in the case of a law, by a super majority or its equivalent. A provision of constitutional force is basic to the functioning of society; it is part of the shared consensus, backed by widespread consent, within which everyday legislation is crafted.

In the United States, repeal of First Amendment protection of freedom of speech is unthinkable, and that was essentially the situation applying to the gold standard for many years. But when the gold standard ceased to have constitutional force as a consequence of the Great Depression, over time Congress repealed legislation providing for gold coins and other features of the gold standard. I think it is true-I hope it is true-that in the United States today the idea that Congress or the Federal Reserve would deliberately aim for, or tolerate, a sustained inflation rate of, say, 8 percent per year is now unthinkable. If so, the idea that the Federal Reserve has a responsibility to maintain low and stable inflation in the neighborhood of recent experience is approaching the level of constitutional force.

I am sure, however, that in many countries debate over a legislated inflation target has been extremely valuable in helping to create a consensus of constitutional force. What I am emphasizing is that such legislation can never be the end of the matter; central bankers and others must constantly explain the reasons for a legislated target to ensure that it is not simply absorbed into the immense mass of legislation on the books of our democratic countries that is widely ignored and largely forgotten.

Because the effectiveness of a central bank in achieving sustained low inflation depends importantly on its credibility, there is no substitute for consistent policies that build market confidence over time. Once credibility is lost, regaining it takes time and a willingness to endure short-run pain, where the short run may be measured in years. Maintaining credibility over time requires institutional strength that transcends current leadership. Absent crisis conditions, policy should evolve relatively slowly over time, with each change studied carefully and then explained fully. Otherwise, the predictability upon which credibility depends may be incomplete. The purpose of sustained low inflation is to minimize price level shocks that upset business planning and redistribute income and wealth arbitrarily. For the same reason, the central bank should strive to avoid surprises in its own policy procedures.

One of the most difficult and hotly debated issues is whether monetary policy should be confined to an inflation objective or should also have an employment or growth objective. My view is that it does not make economic sense for the central bank to have objectives stated in terms of the level of employment or the rate of growth of real gross domestic product (GDP). It is within the power of the central bank to achieve a long-run inflation objective, but not to achieve an objective for the level of employment or the unemployment rate. No organization should be assigned an objective that it cannot achieve or, at best, achieve only temporarily.

I think it is within the power of the central bank, however, to contribute to employment stability. If inflation expectations are solidly held, which is an expected outcome of achieving an inflation objective on a sustained basis, then the central bank can 
reliably change real interest rates in the short run. Provided that the central bank's short-run policy decisions do not shake confidence in the long-run policy, it can direct short-run policy to help cushion employment fluctuations. It is reasonable to interpret a number of episodes in the United States since 1982 in this way; most recently, I think that it is undeniable that the Fed's rapid reduction in its federal funds rate target in 2001 helped to soften the extent of the recession. Of course, we cannot judge the success of a policy by one incomplete episodethe judgment of history might be that policy was too easy too long, although that is certainly not my judgment at this time.

My point is not to offer commentary on recent Federal Reserve policy but to emphasize that success on the inflation front provides the opportunity to employ monetary policy to stabilize, or to work in the direction of stabilizing, short-run fluctuations in real activity. And if I am correct that a central bank that is successful on the inflation front has the power to contribute to economic stability, then I see no reason why a government should not assign a central bank an objective of contributing to stability of the real economy to the extent consistent with the inflation objective. The Federal Reserve operates under a vague legislated instruction-vague in the sense that no numerical targets are specified-to contribute to achieving high employment and price stability. If the statutory language is interpreted as I have suggested, then I think such objectives make perfectly good sense.

A legislated employment stabilization objective complicates the relationship between the elected government and the central bank because the central bank must maintain a long horizon. That horizon is typically considerably longer than the horizon of elected officials who quite naturally and understandably have an intense focus on the next election. Because of the way the economy works, a central bank must be willing to back away from efforts to stabilize income and employment when such efforts threaten the inflation objective. Failing to maintain the primacy of the inflation objective only puts economic stability at risk over the longer run. The United States and many other countries had ample experience with this scenario in the 1970s; excesses in short-run recession fighting created higher inflation over the longer run and deeper recessions later on.

Central bank independence is the institutional design that promises to reconcile the different horizons of elected officials and the central bank. This subject is so important that it deserves special attention.

\section{CENTRAL BANK INDEPENDENCE}

There is widespread agreement that central bank independence leads to better monetary policy. I've introduced the logic of independence by referring to different horizons of elected officials and central banks, but I'm not sure that is the total story. Elected officials do maintain some policies with great continuity over time and make some investments with long payback periods. For two quite different U.S. examples, consider the long horizon behind decisions to invest in national parks and military research.

I note, however, that competition among those seeking electoral office does not work well in the context of central bank leadership. Democratic leaders compete for office promising change and improvement rather than continuity and stability, whereas an incoming central bank governor will almost certainly want to continue the policies of a successful predecessor and will emphasize his commitment to do so. In contrast, I don't think I've ever heard a candidate emphasize that he or she is running for office to continue the policies of a successful predecessor of a different political party. Political independence and nonpartisan monetary policy provide the promise of policy stability over time, which in turn stabilizes expectations in asset markets. Such stability and continuity is essential to a successful monetary policy.

Central bank independence requires that the governor have a substantial term of office and that individual policy decisions not be subject to revision by the government. However, such structural features of the central bank institutional design are only the starting point for central bank independence. If a president publicly attacks the central bank's policies, then independence will certainly be incomplete. This subject is a very difficult one for a democratic society: How can an important area of public policy be off limits for comment and criticism by elected officials? Yet, such criticism clearly unsettles markets and damages the effectiveness of monetary policy.

The only way around this problem, it seems to me, is for the government to exercise great forbearance and confine criticism to internal discussions with the central bank. That has come to be the practice in the United States, but it has not been 
established long enough that it can be regarded as institutionalized. Consideration of this issue makes clear that optimal central bank design goes far beyond legal issues per se; it is ludicrous to consider the possibility of passing a law saying that the president is not allowed to comment on central bank policy! Clearly, though, if the president does not retain confidence in the central bank, the country is in substantial trouble. In this situation, the president must be prepared to replace a failing central bank leadership when terms expire.

Central banking is a governmental function, but I think that some observers most committed to democratic principles overlook the possibility of employing private-sector activity and principles for governmental ends. A well-understood example is the value of using pollution taxes rather than command-and-control regulations to achieve environmental objectives.

The organization of the Federal Reserve System fits this perspective very nicely. Members of the Board of Governors are appointed by the President of the United States and confirmed by the Senate. However, presidents of the Reserve Banks are appointed by the directors of the Reserve Banks, subject to approval by the Board of Governors. Directors of Reserve Banks have powers and responsibilities that are closer to those of a private company than of those of a government agency. At each Reserve Bank, six of the nine directors are elected by the commercial banks that are members of the Reserve Bank; the other three directors are appointed by the Board of Governors on the recommendation of the Reserve Bank. The directors are explicitly nonpolitical; they are drawn from the local community and are not permitted to hold partisan political office or participate in political activity through such activities as heading campaign committees or leading political fund-raising efforts. The directors, in turn, select the Bank president and first vice president, subject to approval by the Board of Governors.

This institutional arrangement clearly involves ultimate control of the Federal Reserve System through the political process centered on the Board of Governors. Yet, a considerable part of the System's leadership obtains office through what is essentially a private-sector process. My own case illustrates the point nicely. I was a university professor in Rhode Island, with no personal or institutional connection to the Federal Reserve Bank of St. Louis. If the appointment of the Bank president were con- trolled by a political process involving, say, the state governors of the states with territory in the Eighth Federal Reserve District (Missouri, Arkansas, Mississippi, Tennessee, Kentucky, Indiana and Illinois), then it is very unlikely that a university professor from the state of Rhode Island would have become Bank president. Nor is it likely that I would have been appointed through a Washington political process, given that I had served in a Republican administration but that a Democratic administration controlled the White House in 1998 when I was named St. Louis Fed president.

What this private-sector process does is to reinforce the nonpolitical nature of the Federal Reserve System. The process also involves the Reserve Bank directors in an important way. The Federal Reserve pays the Bank directors very little; what they get out of service as director is an intense education in monetary policy. Over their years of service, and for years thereafter, the directors spread knowledge of monetary policy processes and challenges throughout their communities. I cannot imagine a more effective way of building support for sound monetary policy than having community leaders from many different professions serve as directors. Consider, for example, the breadth of experience on the current St. Louis board; the board includes CEOs of commercial banks, the managing partner of a major law firm, CEOs of both large and small businesses, a university professor who also manages a family farm, an expert in the venture capital industry, and the CEO of a nonprofit community organization. Some Reserve Banks include trade union leaders; although that is not the case currently for the St. Louis Fed, one of the Bank's branch boards does include a trade union leader. Taking the twelve Federal Reserve Banks together, directors are drawn from every sector of the economy and every geographic region.

Equally important to the Federal Reserve is the flow of information from Reserve Bank directors to Bank presidents, who in turn use this information in formulating monetary policy decisions. Valuable information also comes from numerous advisory committees that meet from time to time at the Board of Governors and the Reserve Banks, and from contacts between Federal Reserve officials and their audiences as they travel to speak at various events and meet with business and community leaders. The Federal Reserve has maintained a continuous association with what are known in the United States as "grass roots" contacts throughout the 
country. Although this organization of the Federal Reserve System did not prevent the monetary policy mistakes that contributed to the Great Depression and the Great Inflation, I believe that the current process contributes greatly to the prospects for continued sound monetary policy in the years ahead.

\section{TRANSPARENCY}

In recent years, central banks have become more open in many different ways. In the past, central bankers often discussed monetary policy in obscure ways and seemed to relish the mystique of central banking. As an academic, I never thought that extensive secrecy served central banks well, and still don't.

Particularly given central bank independence, openness is essential to political accountability. Whether by law or confirmed practice, good central bank design calls for central banks to make timely reports about policy actions, including the reasons for these changes.

I've discussed transparency on several occasions at considerable length; here I want to make two main points. First, prompt disclosure of policy decisions and the rationale for those decisions is essential. However, disclosure of policy debates leading up to decisions must be handled extremely carefully. Excessive disclosure will damage the openness of the internal debate and thereby increase the likelihood of policy mistakes. Moreover, with many different views expressed around the policy table, and views expressed provisionally and for the sake of argument and thoroughness, full disclosure of internal debate without a substantial lag is more likely to confuse markets than enlighten them. I believe that the Federal Reserve practice of disclosing the transcript of Federal Open Market Committee (FOMC) meetings with a five-year lag works well. A lag of that length maintains ultimate accountability and provides a valuable record for scholars while preventing damage to the policy process.

My second main point is that prompt disclosure of policy decisions and their rationale is necessary for markets to function efficiently. Monetary policy works through markets; if markets expect one policy direction when the central bank intends another, both the markets and the central bank are likely to be surprised at some point and disappointed by the results.

\section{CONCLUSION}

There is no uniquely optimal way to write a central bank law and to institutionalize central bank practices. Different countries have different histories and different preferences. Let me pull together the threads of my argument: A good design for the central bank will contain three main elements.

First, the government should assign clear and obtainable objectives to the central bank. I favor a legislated inflation target, but more important than legislation is an understanding in the society that low and stable inflation is the central bank's responsibility and that the bank should be judged on how well it achieves that objective. A government may assign to the central bank a policy goal of contributing to stability in income and employment, provided there is a clear understanding that there can be no central bank target for the level of employment or the rate of growth of GDP.

Second, the central bank should operate independently within the government; the governor should have a reasonably long term of office and should not be subject to removal by the president, except for cause through an impeachment process. The president should not be able to overturn individual monetary policy decisions and ideally should confine comment on those decisions to confidential communications with the central bank.

Third, the central bank should be transparent in the way it makes decisions and implements policy. Political accountability requires transparency; so also does the efficient operation of the markets through which monetary policy affects the economy.

These three principles broadly characterize all major central banks today. We should not, however, take that fact as reason to assume that the issue is settled. We are bound to face stresses in the future when many will question these principles. Stating them now, defending them and explaining them, is our best hope for improving public understanding and maintaining the progress of recent years that is so evident to all central banks and students of central banking. 
SEPTEMBER/OCTOBER 2003 